\title{
CDISC SDTM Death Diagnosis Test Code Terminology
}

National Cancer Institute

\section{Source}

National Cancer Institute. CDISC SDTM Death Diagnosis Test Code Terminology. NCI

Thesaurus. Code C116108.

Terminology associated with the death detail test code codelist of the Clinical Data

Interchange Standards Consortium (CDISC) Study Data Tabulation Model (SDT M). 